\title{
Some deformed specimens of Mystus bleekeri (Day) and Labeo bata (Ham. Buch) from the river Chenab in Pargwal wetland, Akhnoor, Jammu
}

\author{
S. P. S. Dutta \\ Emeritus Fellow (UGC), Department of Environmental Sciences, University of Jammu, Jammu (J\&K), INDIA \\ E-mail: duttasps@gmail.com \\ Received: December 21, 2015: Revised received: February 15, 2016; Accepted: March 22, 2016
}

\begin{abstract}
Four adult deformed specimens of Mystus bleekeri showing caudal fin deformities viz complete degenerated caudal fin, degenerated upper caudal fin lobe, degenerated lower caudal fin lobe and truncated caudal peduncle and bulbous caudal fin base and one specimen of Labeo bata with a blunt head and terminal mouth were observed among the fish collections from the river Chenab in Pragwal wetland area and have been described. Deformities in M. bleekeri are most probably caused by Myxobolus infection and in L. bata it is the result of injury.
\end{abstract}

Keywords: Deformed, Injury, Labeo bata, Mystus bleekeri, Myxobolus sp, Pragwal wetland, The River Chenab

\section{INTRODUCTION}

Deformities in wild fish populations in Himalayan lotic waters though rare have earlier been reported from the Jammu region by Dutta (1989-90), Dutta and kour (1994), Dutta et al. (1989, 1993 and 1996), Shekhar and Dutta (1993) and Kour et al. (1997). During the hydrobiological studies of the river Chenab, over a period of three years, deformed specimens of Mystus bleekeri and Labeo bata were observed among the collections made by fishermen in Pragwal wetland area and have been reported. The objective of this study is to have information about teratology in wild fish population from Himalayan lotic waters as such studies are indicators of water quality. The study will provide baseline data to the future workers interested in fish teratology.

\section{MATERIALS AND METHODS}

Deformed specimens of Mystus bleekeri and Labeo bata were purchased from fishermen sampling fish in Pragwal wetland area and studied for morphological aberrations. These deformed fishes along with normal specimens were exposed to X-rays (Rays India, Digital $\mathrm{X}$-ray machine) for detailed skeletal analysis.

\section{RESULTS}

Mystus bleekeri (Day) Four deformed specimens of $M$. bleekeri showing caudal fin deformities were seen in the collections made by fishermen from back waters of the river Chenab in the Pragwal area and are described as below:-

Complete degenerated caudal fin lobes:In a normal fish, caudal fin is bilobed with 17 fin rays (Figs.

1a). The two lobes are unequal and the upper lobe is longer than the lower fin lobe (Figs. 1a, b). In this aberrant fish, measuring $6.5 \mathrm{~cm}$ and weighing $8 \mathrm{gm}$, caudal fin lobes are degenerated and only one short fin ray in the lower fin lobe is present (Figs. 2a, b). Microscopic observations revealed the presence of 11 rudimentary fin rays. There was a blister in the caudal peduncle region and its study revealed the presence of Myxobolus, sporozoan, protozoan parasite spores in large number.

Degenerated lower caudal fin lobe: This specimen of $M$. bleekeri, measuring $9 \mathrm{~cm}$ and weighing $10 \mathrm{gm}$, showed totally degenerated lower fin lobe (Figs. 3a, b). The upper lobe with 8 fin rays is normal. Microscopic examination of a wound in the caudal region, revealed the presence of the Myxobolus spores in large number. Truncated caudal peduncle with bulbous caudal fin base: Measuring $10.5 \mathrm{~cm}$ and weighing $17 \mathrm{gm}$, this specimen of $M$. bleekeri was recognised by a truncated caudal peduncle with bulbous and short caudal fin base (Figs. 4a, b). Upper caudal fin lobe is normal and in the lower caudal fin lobe only 5 fin rays are present. Microscopic examination of bulbous caudal peduncle revealed the presence of Myxobolus spores in large number.

Degenerated upper caudal fin lobe: Measuring 13.8 $\mathrm{cm}$ and weighing $25 \mathrm{gm}$, this deformed specimen of $M$. bleekeri was recognised by degenerated upper caudal fin lobe and rudimentary fin rays. The lower caudal fin lobe is normal. Microscopic study of caudal fin revealed the presence of the Myxobolus spores in large number.

In these four abnormal fishes, there is no deviation in the placement of fins and fin rays in dorsal, pectoral, pelvic and anal fin from a normal fish. Surprisingly, X- 


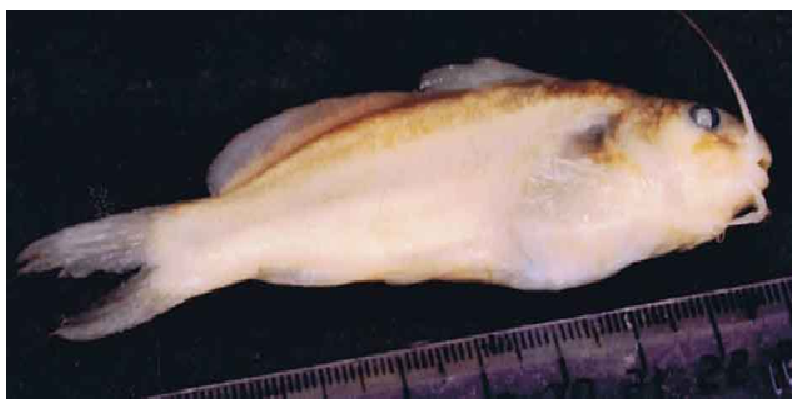

Fig. 1a: Photograph of a normal specimen of Mystus bleekeri (Day).

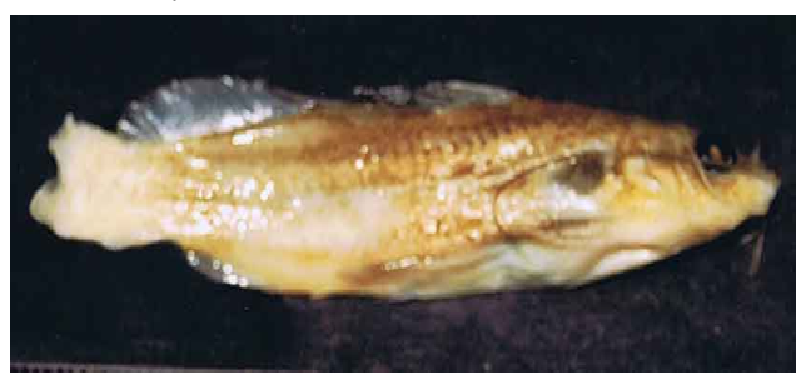

Fig. 2a: Photograph of Mystus bleekeri (Day) showing totally degenerated caudal fin lobes.

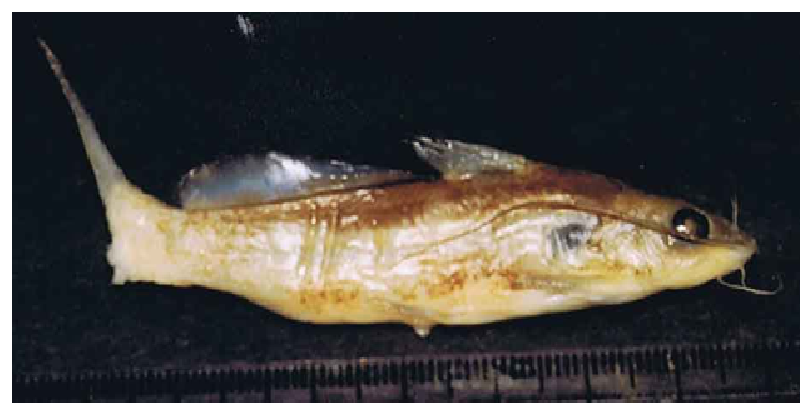

Fig. 3a. Photograph of Mystus bleekeri (Day) showing totally degenerated lower caudal fin lobe.

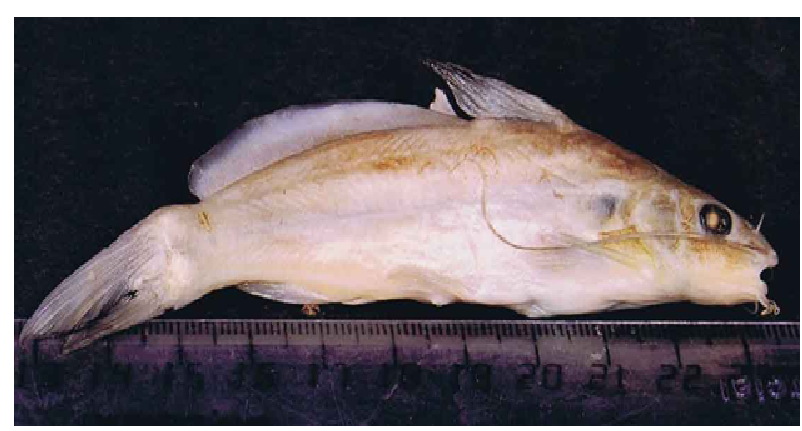

Fig. 4a: Photograph of Mystus bleekeri (Day) showing truncated caudal peduncle with blubous caudal fin base.

ray analysis (Figs. 2b, 3b, 4b) did not show any clear structure of vertebral column in any of these abnormal fishes and is unexplainable. Although in a normal fish, measuring $9.8 \mathrm{~cm}$ and weighing $13 \mathrm{gm}$, streamlined vertebral column is clearly visible (Fig. 1b).

Labeo bata (Ham-Buch) A single aberrant specimen of L. bata, measuring $29 \mathrm{~cm}$ and weighing $190 \mathrm{gm}$, was recognised by its blunt head and terminal mouth (Figs. 5a, b). In a normal fish, mouth is ventral and

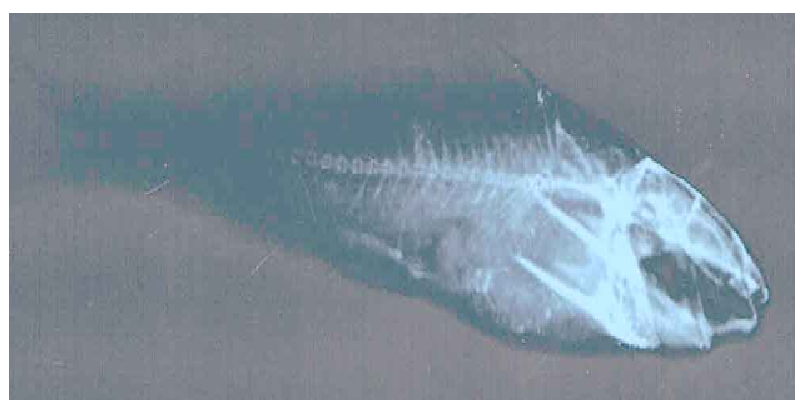

Fig. 1b. X-ray photograph of a normal specimen of Mystus bleekeri (Day).

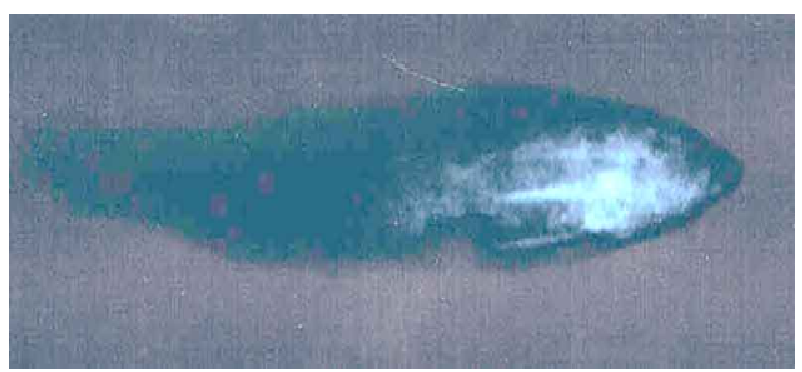

Fig. 2b. X-ray photograph of Mystus bleekeri (Day) with totally degenerated caudal fin lobes.

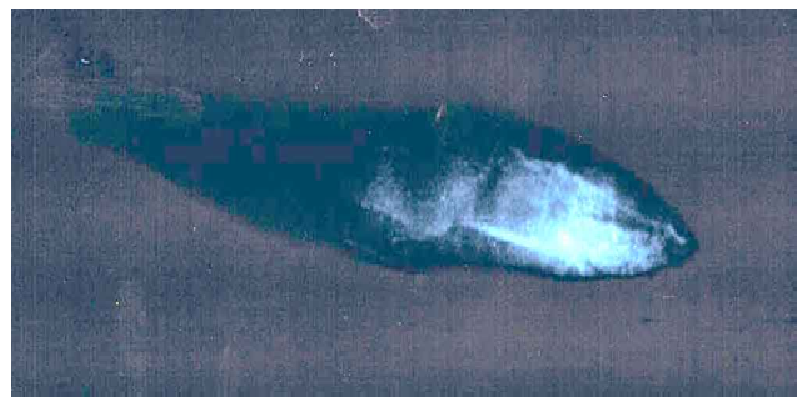

Fig. 3b: X-ray photograph of Mystus bleekeri (Day) with totally degenerated lower caudal fin lobe.

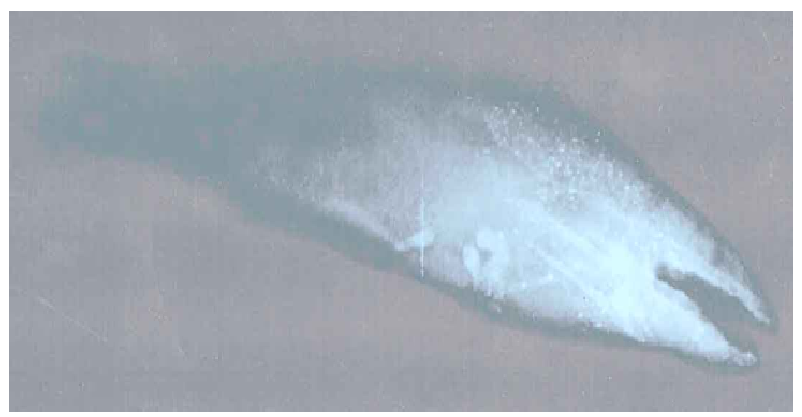

Fig. 4b: X-ray photograph of Mystus bleekeri (Day) with truncated caudal peduncle with blubous caudal fin base.

upper jaw over hangs lower jaw (fig. 5c). X-ray study revealed short and blunt head and terminal position of mouth in this abnormal fish (Fig. 5d). Placement of fins and count of fin rays in dorsal, pectoral, pelvic, anal and caudal fin is same in both normal and abnormal fish. However, there is some deviation in the ratios of head length in total body length/standard body length in normal (7/5.2) and abnormal fish (6.5/4.9). 


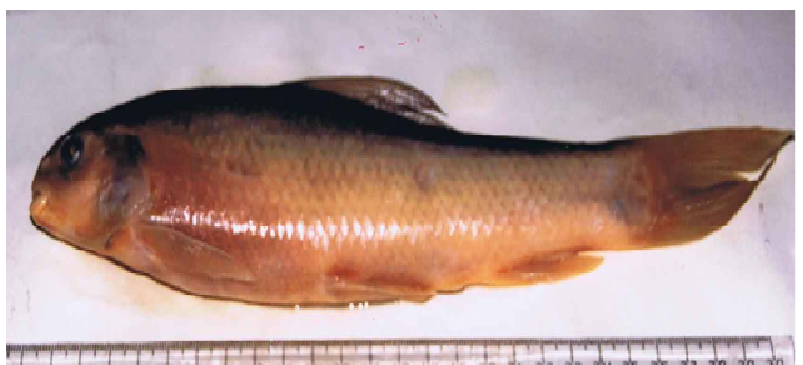

Fig. 5a: Photograph of Labeo bata (Ham. Buch) showing blunt head and terminal mouth.

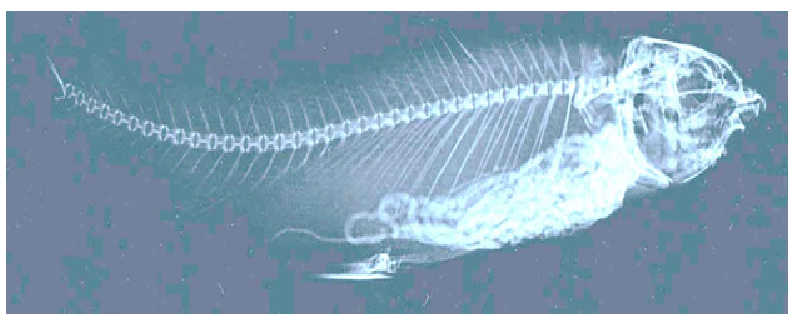

Fig. 5c: X-ray photograph of a normal specimen of Labeo bata (Ham. Buch).

\section{DISCUSSION}

Aberrations in wild fish populations have been ascribed to water temperature fluctuations (Hubbs, 1959; Al-Hassan, 1982 and Wang and Tsai, 2000), currents (Backiel et al., 1984; Chaitan, 1994; Divanach et al., 1997 and Dutta, 2012); inadequate light intensity, temperature and salinity (Johnson and Katavic, 1984); fluctuations in one or other chemical parameters like salinity, low dissolved oxygen, high carbon dioxide (Lee and Williams, 1970; Martens et al., 2006; Jawad and Oktner, 2007; Lall et al., 2007 and Sun et al., 2009) and water quality degradation caused by the pollutants (Kent et al., 2004; Subba, 2004, Villeneuve et al., 2005 and Sun et al., 2009).

Optimum range of various physico-chemical characteristics of water (water temperature, $8-16^{\circ} \mathrm{C}$; transparency, nil-240 cm; turbidity, 2.3-942.33 NTU ; pH, 8.23 -8.46; conductivity, $140.05-308.47 \mu \mathrm{S}$; total dissolved solids, 63.90-140.88mg/l ; salinity, 0.2 ppt ; DO, 6.24$13.08 \mathrm{mg} / \mathrm{l}$; BOD, 1.07-5.56 mg/l ; Free $\mathrm{CO}_{2}$, nil ; carbonate, $1.16-3.97 \mathrm{mg} / \mathrm{l}$; bicarbonate, 54.27-116.25 $\mathrm{mg} / 1$; chloride, 2.33-9.28 mg/1 ; calcium, 14.79-32.49 $\mathrm{mg} / \mathrm{l}$; magnesium, 3.87-10.13 mg/l ; total hardness, 58.52-119.56 mg/1 ; sodium, 1.11-1.69 mg/l ; potassium, 1.23-2.54 mg/l ; phosphate, 0.040-0.075 mg/1 ; nitrate, $0.145-0.323 \mathrm{mg} / \mathrm{l}$; silicate, $4.08-9.33 \mathrm{mg} / \mathrm{l}$; sulphate, $11.35-19.30 \mathrm{mg} / \mathrm{l}$ and below detection level of chromium, nickel, zinc, lead and copper) in the river Chenab suggests that these aberrations are not due to water quality degradation caused by pollutants.

Microscopic examination of caudal region of deformed Mystus bleekeri has shown Myxobolus spores infection and may be responsible for causing caudal fin aberrations. Fish vertebral anomalies due to Myxobolus in-

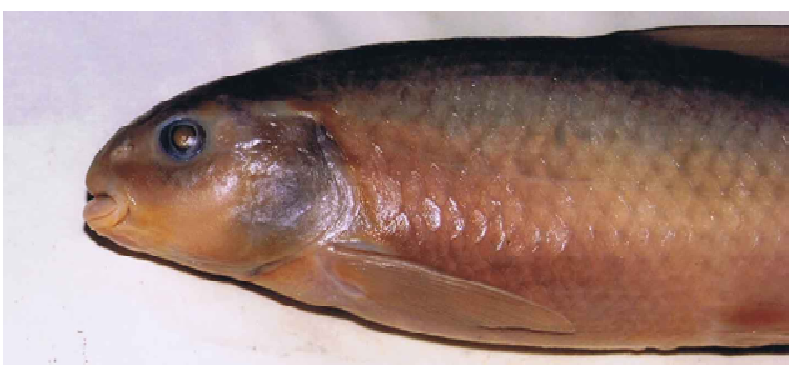

Fig. 5b: Enlarged head of Labeo bata (Ham. Buch) showing blunt head and terminal mouth

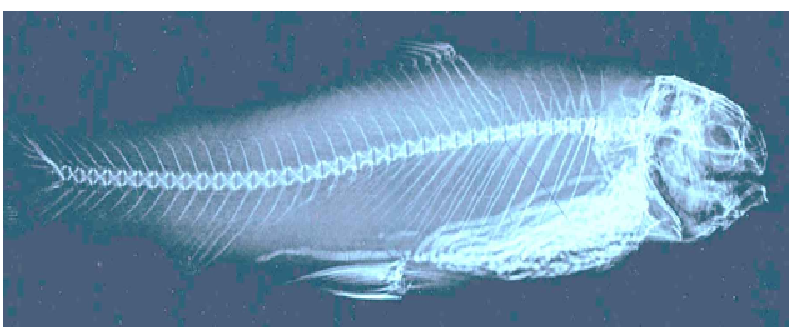

Fig. 5d: X-ray photograph of deformed Labeo bata (Ham. Buch) showing loss of some frontal bones and terminal mouth..

fection have been documented by Needham and Wooten (1971), Kent et al., (2004), Villenuve et al., (2005) and Yokoyama et al., (2005), but there is no record of caudal fin deformity as is observed during present study. Short and blunt head and loss of anterior cephalic bones and terminal position of mouth in $\mathrm{La}$ beo bata is most probably due to injury in torrential river Chenab in the early stages of the development and its healing. This is in agreement to the earlier observation of the Kour et al., (1997) for Tor tor and Barilius bendelisis.

\section{ACKNOWLEDGEMENTS}

This paper is a part of the project sanctioned by the UGC, New Delhi, and is acknowledged for financial help. I express my thanks to the UGC, New Delhi, for awarding Emeritus Fellowship. Head, Department of Environmental sciences, University of Jammu, is acknowledged for providing necessary facilities in the department.

\section{REFERENCES}

Al-Hassan, L. A. J. (1982). Vertebral deformities in fishes from Iraq and united Arab Emirates, Arabians, Gulf Iraqi Jour. Mar. Sci., 1(1): 13-23.

Backiel, J., Kokurewicz, B. and Ogorzalek, A. (1984).High incidence of skeletal anomalies in carp, Cyprinus carpio, reared in cages in runing water. Aquaculture, 43: 369-380.

Chaitan, B. (1994). Abnormal swim bladder developmentand lordosis in sea bass (Dicentrachus labrax) and sea bream (Sparus auratus). Aquaculture, 119: 371-379.

Divanach, P., Papandroulakis, N., Anastasiadis, P., Koumoundouros, G. and Kentouri, M. (1997). Effects of water currents on the development of skeletal deformi- 
ties in seabass (Dicentrachus labrax L.) with functional swimblader during post larval and nursery phase. Aquaculture, 156: 145-155.

Dutta S. P. S. (1989-90). Vertebral deformity in Barilius vagra (Ham) from Jammu. Matsya, 15-16: 166-168.

Dutta S. P. S. (2012). Limnology of the river Chenab, at Akhnoor, Jammu. Part II Deformities in Schizothoracichthys esocinus (Heckel) Tor putitora (Ham-Buch) Tor tor (Ham-bach) Labeo rohita (Ham-Bcah) and Mystus bleekeri (Day). Project Report, Submitted to the UGC, New Delhi; pp-74.

Dutta, S. P. S. and Kour, H. (1994). Pelvic fin deformity in Schizothorax richardsonii (Gray and Hard) inhabiting Rajouri River (Jammu and Kashmir) J. Freshwater Fish Biol., 6: 195-196.

Dutta, S. P. S., Kour, H. and Sharma J. (1996). Occurrence of Malformed specimen of Labeo rohita (Ham.-Buch) in river Tawi, Jammu. J. NATCON., 8: 147-149.

Dutta, S. P. S., Malhotra, Y. R., Sharma, K. K., Gupta K. and Sinha, P. (1989). Deformities in some freshwater fihes of Jammu (J\&K). Proc. Nat. Acad. Sci., India, 59: 451-453.

Dutta, S. P. S., Sharma, J. and Kaul, V. (1993). A runcated specimen of Garra lamata (Ham). J. NATCON., 5(2): 115-116.

Hubbs, C. (1959). High incidence of vertebral deformty in two natural populations of fishes inhabiting warm water springs. Ecology, 40: 154-155.

Jawad, L. A. and Oktner, A. O. (2007). Incidence oflordosis in freshwater mullets, Liza abu (Heckel, 1843) collected from Ataturk lake, Turkey. Anales de Biologia, 29: 105113.

Johnson, D. W. and Katavic, I. (1984). Mortality, gowth and swimbladder stress in syndrome of sea bass (Dicentrachs latrax) larvae under varied environmental concentrations. Aquaculture, 38: 67-71.

Kent, M. L., Watral, V. G., Whipps, C. M., Cunningham, M. E., Crisctone, C. D., Heidel, J. R., Curtis, L. R., Spitsbergen, J. and Markle, D. F. (2004). A digenean meta cescaria (Apophallus sp.) and a Myxozoan (Myxobolus sp.) associated with vertebral deformities in cyprinoid fishes from the Willamette River, Oregon. J. of Aquatic Animal Health, 16: 116-129.

Kour, H., Koul, V. and Dutta S. P. S. (1997). Deformities in some freshwater fishes of Jammu. J. Freshwater Biol., 18(4): 213-216.

Lee, C. H. and William, W. D. (1970). Abnormality infishes due to salinity fluctuations. J. Fish Biol., 2: 55.

Martens, L. G., Witten, P. E., Fivelstad, S., Haysstune, A. Sulvaried, B., Vikesa, V. and Oback, A. (2006) Impact of high water carbon dioxide on Atlantic Salmon Smelts (Salmo salar L.) on fish performance, vertebral composition and structure. Aquaculture, 261(1): 80-86.

Neefham, T. and Wootten, R. (1978). The parasitology of teleosts. In: Fish pathology. R. Roberts (Ed). Balliere Tindall London England, pp 144-182.

Shekhar, C and Dutta, S. P. S. (1993). An abnormal specimen of the of Schizothorax richardsonii (Gray and Hard) with vertebral deformity. Him. J. Envir. and Zool., 7: 101-102.

Subba, B. R. (2004). Anomalies in bighead carp,Aristichthys nobilis and African cat fish, Clarias gariepinus, in Baratinagar, Nepal. Our Nature, 2: 41-44.

Sun, P. L., Hawkins, W. E., Overstreet R. M. and BrownPeterson, N. J. (2009). Morphological deformities as biomarkers in fish from contaminated rivers in Taiwan. Int. J. Envir. Res. Public health, 6: 2307-2331.

Villeneuve, D. L., Curtis, L. R. Jenkins, J. J. Warner, K. E. Tilton, F., Kent, M. L., Watral, V. G., Cunningham, M. E., Markle, D. F., Sethajintanin, D., Krissanakriangkrai, O., Jhonson, E.R., Grove, R. and Anderson, K. A. (2005). Environmental stress and skeletal deformities in fish from the Willmette River, Oregen. Environmental Science and Technology, 39(10): 3495-3506.

Wang, L. H. and Tsai, C. L. (2000) Effects of temperature on deformity and sex differentiation of Tilapia, Oreochrouris mossumbicus. J. Expt . Zool., 286: 534-537.

Yokoyama, H., Freeman, M.A., Itoch, N. And Fukuda, Y. (2005). Spinal curvature of cultured Japanese mackerls associated with a brain myxosporean Myxobolus acanthogobii. Dis Aquacult. Org., 66: 1-7. 